\title{
Efektivitas Website Sebagai Media E-Government dalam Meningkatkan Pelayanan Elektronik Pemerintah Daerah (Studi Pada Website Pemerintah Daerah Kabupaten Jombang)
}

\author{
Santy Nurina Aprilia ${ }^{1}$, Andy Fefta Wijaya ${ }^{2}$, Suryadi ${ }^{2}$ \\ ${ }^{1}$ Program Magister IImu Administrasi Publik, Fakultas IImu Administrasi, Universitas Brawijaya \\ ${ }^{2}$ Fakultas Ilmu Administrasi, Universitas Brawijaya
}

\begin{abstract}
Abstrak
Semakin berkembangnya ilmu pengetahuan dan teknologi, pemerintah dituntut untuk lebih meningkatkan kinerja pelayanan public khususnya pelayanan publik berupa layanan elektronik atau e-service, khususnya dalam hal ini adalah website, dimana website pemerintah daerah diharapkan dapat menjadi media e-government sebagai sarana interaksi antara pemerintah dengan masyarakat maupun mempermudah layanan elektronik. Penulisan Tesis dengan judul "Efektivitas Website Sebagai Media E-government dalam Meningkatkan Pelayanan Elektronik Pemerintah Daerah (Studi Pada Pemerintah Daerah Kabupaten Jombang)" merupakan sebuah studi dimana dalam penelitian ini diharapkan dapat mengetahui seberapa efektif website pemerintah daerah sebagai media e-government. Tujuan Penelitian ini adalah: Untuk menjelaskan dan menganalisis efektivitas website sebagai media e-government dalam meningkatkan pelayanan elektronik pemerintah daerah di Kabupaten Jombang; Untuk menjelaskan dan menganalisis faktor pendukung efektivitas website sebagai media e-government dalam meningkatkan pelayanan elektronik pemerintah daerah di Kabupaten Jombang; Untuk menjelaskan dan menganalisis faktor penghambat efektivitas website sebagai media $e$ government dalam meningkatkan pelayanan elektronik pemerintah daerah di Kabupaten Jombang. Hasil temuan di lapangan menunjukkan bahwa website Pemerintah Kabupaten Jombang telah efektif sebagai media pemberi informasi kepada masyarakat, namun belum efektif sebagai media dalam memberikan pelayanan publik secara elektronik ( $e$ service) seperti mendownload blangko, formulir, dll.
\end{abstract}

Kata kunci: Efektivitas, E-government, E-service, Media, Teknologi Informasi, Website

\begin{abstract}
Background of research is the development of science and technology, the government is expected to further improve the performance of public services, especially public services such as electronic services or e-services, in particular in this case is the website, where the local government website is expected to be the medium of e-government as means of interaction between the government and the community and facilitate electronic service. Thesis writing under the title " For the Media Website Effectiveness in Improving E-government Services Local Government (Local Government Studies in Jombang ) " is a study which in this study are expected to know how effective local government website as a medium of e-government. The purpose of this study is: To describe and analyze the effectiveness of the website as a medium of $e$-government in improving electronic services in Jombang local government; For describing and analyzing the factors supporting the effectiveness of the website as a medium of e-government in improving electronic services in Jombang local government; For explain and analyze the factors inhibiting the effectiveness of the website as a medium of $e$ government in improving local government electronic services in Jombang. The findings in the field shows that the Government website Jombang has been effective as a conduit of information to the public media, but the media has not been as effective in providing electronic public services ( e-services) such as downloading blank, form, etc. .
\end{abstract}

Keywords: Effectiveness, E-government, E- services, Information Technology, Media, Website

\section{PENDAHULUAN}

Pemerintah daerah dituntut untuk dapat memberikan pelayanan publik yang efektif, hal ini seiring dengan makin berkembangnya ilmu pengetahuan dan teknologi. Marshall McLuhan dalam bukunya Understanding Media,

Corresponding Address:

Santy Nurina Aprilia

Email : santy_fairy@yahoo.com

Alamat : Fakultas Ilmu Administrasi Universitas Brawijaya JI. MT. Haryono 163 Malang 65145 mengatakan bahwa media itu "The Extension of Man" (media itu perluasan manusia). Dapat dikatakan, media menjadi 'kepanjangan' tangan manusia. Apa yang menjadi keinginan, cita-cita, dan tujuan seorang manusia bisa diperluas oleh media. Media dengan jangkauan yang dimilikinya akan meluaskan banyak hal pada diri manusia, menerobos ruang dan waktu. Banyak media yang bisa dijadikan alat oleh pemerintah untuk menyampaikan informasi kepada masyarakat. Salah satu cara untuk memberikan layanan e- 
government kepada masyarakat yaitu berupa website Pemerintah Daerah, yang bertujuan untuk meningkatkan layanan Elektronik ( $E$ Service), dimana memudahkan masyarakat dalam mengakses informasi, layanan, dan lain-lain [1].

Tujuan pokok good governance adalah tercapainya kondisi pemerintahan yang dapat menjamin kepentingan pelayanan publik secara seimbang dengan melibatkan kerjasama antar semua komponen pelaku (negara, masyarakat madani, lembaga-lembaga masyarakat, dan pihak swasta). menyatakan bahwa salah satu wujud tata kepemerintahan yang baik (good governance) adalah terdapatnya citra pemerintahan yang demokratis [2].

Sejak pertama kali diluncurkan pada tahun 2003, website Pemerintah Kabupaten Jombang dikelola oleh Bagian Humas Sekretariat Pemerintah Kabupaten Jombang, namun semenjak tahun 2009 website Pemerintah Kabupaten Jombang dikelola oleh webmaster dibawah pengelolaan Kantor Arsip dan PDE (Pengolahan data elektronik) Kabupaten Jombang yang dikelola oleh seksi pengolahan data elektronik, dimana pada tahun 2009 ada penggabungan Instansi dan terbentuk kembali Kantor Arsip, PDE (Pengolahan data elektronik) dan Perpustakaan Kabupaten Jombang. Hal tersebut dilakukan untuk lebih mengembangan Teknologi Informasi khususnya website Pemerintah Kabupaten Jombang agar lebih terkelola dengan baik [3].

Untuk e-government sendiri, pada tahun 2006 Pemerintah Kabupaten Jombang pernah memperoleh e-government award sebagai terbaik ketiga kategori Pemerintah Kabupaten/Kota Sebagai Lembaga Pemerintah Pengaplikasi e-government pada tahun 2006 oleh media Warta Ekonomi, dimana dalam hal ini pemerintah Kabupaten Jombang dinilai telah berhasil mengaplikasikan e-government berupa website Pemerintah Daerah Kabupaten Jombang. Hal tersebut tentu saja menjadi acuan pemerintah Kabupaten Jombang untuk terus memperbaiki kualitas dan kinerja guna untuk memberikan informasi dari media e-government khususnya website yang dapat digunakan dan dimanfaatkan masyarakat Jombang untuk dapat memperoleh informasi, menyampaikan aspirasi dan berinteraksi dengan pemerintahannya. Oleh sebab itu Pemda Jombang berusaha terus melakukan inovasi dari tahun ke tahun guna untuk terus memperbaiki kualitas website Pemda Jombang sebagai media e-government agar masyarakat bisa mendapatkan informasi serta interaksi yang terbaik sebagi bentuk pelayanan publik melalui media website.

Diharapkan dengan adanya penelitian mengenai Efektivitas Website Sebagai Media Egovernment dalam Meningkatkan Pelayanan Elektronik Pemerintah Daerah Kabupaten Jombang, dapat diketahui seberapa besar efektivitas suatu media e-government dalam mempermudah pelayanan pemerintah kepada masyarakat.

Dengan pemaparan tersebut, maka dapat dilihat mengenai urgensi mengenai adanya website Pemerintah Daerah Kabupaten Jombang sebagai media e-government. Oleh karena itu, pentingnya dilakukan penelitian tentang Efektivitas Website Sebagai Media E-government dalam Meningkatkan Peayanan Elektronik Pemerintah Daerah (Studi pada Website Pemerintah Daerah Kabupaten Jombang).

Dari permasalahan diatas, maka tujuan dari kegiatan penelitian ini adalah:

1. Untuk menjelaskan dan menganalisis efektivitas website sebagai media e-government dalam meningkatkan pelayanan elektronik pemerintah daerah di Kabupaten Jombang.

2. Untuk menjelaskan dan menganalisis faktor pendukung efektivitas website sebagai media e-government dalam meningkatkan pelayanan elektronik pemerintah daerah di Kabupaten Jombang.

3. Untuk menjelaskan dan menganalisis faktor penghambat efektivitas website sebagai media e-government dalam meningkatkan pelayanan elektronik pemerintah daerah di Kabupaten Jombang.

\section{METODE PENELITIAN}

Metode yang digunakan dalam penelitian ini adalah kualitatif deskriptif. Penelitian ini, data yang dikumpulan adalah berupa kata-kata, bukan berupa angka-angka.Penelitian kualitatif menurut Abercrombie, Hill, Turner merupakan suatu penelitian yang dicirikan oleh tujuan penelitian yang ingin memahami gejala-gejala yang tida $\mathrm{k}$ memerlukan kuantifikasi atau gejalagejala yang tidak memungkinkan untuk diukur secara tepat atau kuantitatif [4].

Tipe penelitian ini menggunakan pedekatan kualitatif dengan metode deskriptif. Metode ini menurut Lincoln dan Guba bertujuan untuk membuat deskripsi secara sistematis, faktual dan 
akurat tentang fakta-fakta dari objek yang telah diteliti [5].

Dengan demikian penelitian ini berupaya mendeskripsikan, menguraikan, menginterprestasikan permasalahan serta kemudian mengambil kesimpulan dari permasalahan tersebut tentang Efektivitas Website Sebagai Media E-government dalam Meningkatkan Pelayanan Elektronik Pemerintah Daerah.

Fokus Penelitian

Fokus menurut Moleong sangat diperlukan dalam kegiatan penelitian, karena dalam penentuan fokus penelitian memiliki dua tujuan yaitu: (1) Penetapan fokus penelitian akan membahas study yang akan dibahas oleh peneliti; dan (2) Penetapan fokus berfungsi untuk memenuhi kriteria inkusi-ekslusi (memasukkanmengeluarkan) suatu info yang diperoleh dari lapangan [6].

Jadi sasaran atau fokus yang menjadi titik pangkal dalam penelitian ini adalah membahas tentang efektivitas website sebagai media $e$ government. Dengan demikian yang menjadi fokus penelitian ini adalah:

1. Efektivitas efektivitas website sebagai media e-government dalam meningkatkan pelayanan elektronik pemerintah daerah di Kabupaten Jombang, dengan tolak ukurnya yaitu:

a.Peran website Pemerintah Daerah Kabupaten Jombang sebagai media $e$ government dalam meningkatkan pelayanan elektronik

b. Peran Pemerintah Daerah dalam penggunaan Website Sebagai Media Egovernment

c. Tujuan peningkatan pelayanan publik Pemerintah Kabupaten Jombang melalui website

d. Jangkauan akses e-government

e. Content e-government

f. Interaksi e-government

2. Faktor pendukung efektivitas website sebagai media e-government dalam meningkatkan pelayanan elektronik pemerintah daerah di Kabupaten Jombang

3. Faktor penghambat efektivitas website sebagai media e-government dalam meningkatkan pelayanan elektronik pemerintah daerah di Kabupaten Jombang Lokasi Penelitian

Adapun yang dimaksud dengan lokasi penelitian adalah tempat dimana peneliti melakukan penelitiannya. Dalam hal ini yang menjadi lokasi penelitian dalam penelitian ini adalah Kabupaten Jombang. Lokasi secara spesifik dalam penelitian ini adalah Sekretariat Daerah Pemerintah Kabupaten Jombang, Jl. KH. Wachid No. 137 Kabupaten Jombang

Alasan pemilihan lokasi tersebut adalah dikarenakan di Kantor Sekretariat Daerah Pemerintah Daerah Kabupaten Jombang terdapat gedung Kantor Arsip, Perpustakaan dan PDE (Pengelolaan Data Elektronik) tempat untuk para webmaster (sebutan orang yang mengelola website) yang ditunjuk oleh Pemerintah Kabupaten Jombang dalam mengelola Website Pemerintah Kabupaten Jombang,

Pada Pemerintah Kabupaten Jombang pengelolaan website diserahkan kepada kantor Arsip dan PDE yang letaknya di lantai 3 kantor sekretariat Pemerintah Kabupaten Jombang dan dibawah ini profil kantor Arsip dan PDE Pemerintah Kabupaten Jombang, dengan sejarah instansi:

1. Tahun 2001 terbentuk Kantor Arsip dan PDE Kabupaten Jombang

2. Tahun 2005 Kantor Arsip dan PDE Kabupaten Jombang dihapus kemudian menjadi salah satu bagian di Sekretariat

3. Tahun 2009 ada penggabungan Instansi dan terbentuk kembali Kantor Arsip, PDE dan Perpustakaan Kabupaten Jombang

Sehingga dari tempat tersebut dapat diketahui bagaimana pengelolan isi dari website Pemerintah Derah Jombang, sehingga dari tempat tersebut, dapat diketahui bagaimana proses pembuatan, pengelolaan, hingga aksesnya kepada masyarakat dan efektivitasnya dalam melayani publik melalui media online website.

Subjek Penelitian

Subjek yang diteliti dalam penelitian ini adalah kantor Sekretariat Daerah Kabupaten Jombang yang website Pemerintah Daerah Kabupaten Jombang.

Penelitian ini menekankan pada pemilihan subjek yang didasarkan pada kualitasnya. Jumlah subjek yang akan diteliti berjumlah 5 orang, yaitu 1 webmaster yang bertugas untuk mengupdate dan mengelola website Pemda Jombang, 1 Kepala Kantor Arsip, Perpustakaan Dan PDE (Pengelolaan Data Elektronik) Pemerintah Kabupaten Jombang yang bertugas untuk bertanggung jawab atas pengelolaan website, serta 3 orang masyarakat yang aktif menyampaikan aspirasinya di website Pemda Jombang di link "buku tamu" Informan

Informan adalah orang-orang yang benarbenar mengetahui dan atau terlibat langsung 
dengan fokus permasalahan sehingga peneliti dapat merangkum informasi yang penting dalam fokus penelitian.Untuk memperoleh data guna kepentingan penelitian serta adanya hasil yang representatif, maka diperlukan informan kunci (mengingat penelitian ini adalah studi kasus) yang memahami dan mempunyai kaitan dengan permasalahan yang sedang dikaji/diteliti melalui informan kunci. Informan kunci (key informan), informan awal dipilih secara purposive (purposive sampling). Sedangkan informan selanjutnya ditentukan dengan cara "snowball sampling", yaitu dipilih secara bergulir sampai menunjukkan tingkat kejenuhan informasi [7].

Dalam penelitian ini, peran informan sangat penting dan perlu. Untuk menentukan informan dalam konteks objek penelitian diklasifikasikan berdasarkan kompetensi tiap-tiap informan. Teknik penentuan informan dilakukan secara purposif. Usia dan peran informan menjadi salah satu kunci untuk memperoleh informasi yang memadai. Jumlah informan menjadi pengecualian ketika informasi yang diperoleh sudah dipandang memadai sehingga pencaharian informasi "data" dapat dihentikan. Dalam menentukan informan pertimbangannya adalah:

1. Keakuratan dan validitas informasi yang diperoleh. Berdasarkan hal ini maka jumlah informan sangat tergantung pada hasil yang dikehendaki. Bila mereka yang menjadi informan adalah orang-orang yang benar-benar menguasi masalah yang diteliti, maka informasi tersebut dijadikan bahan analisis.

2. Jumlah informan sangat bergantung pada pencapaian tujuan penelitian, artinya bila masalah-masalah dalam penelitian yang diajukan sudah terjawab dari 5 (lima) informan, maka jumlah tersebut adalah jumlah yang tepat.

3. Peneliti diberi kewenangan dalam menentukan siapa saja yang menjadi informan, tidak terpengaruh jabatan seseorang. Bisa saja peneliti membuang informan yang dianggap tidak layak.

Pada Penelitian ini, peneliti mewawancarai 5 (lima) informan, yaitu 1 (satu) webmaster yang bertugas untuk mengupdate dan mengelola website Pemda Jombang, 1 Kepala Kantor Arsip, Perpustakaan Dan PDE (Pengelolaan Data Elektronik) Pemerintah Kabupaten Jombang yang bertugas untuk bertanggung jawab atas pengelolaan website, serta 3 orang masyarakat yang aktif menyampaikan aspirasinya di website Pemda Jombang di link "buku tamu". Dari kelima informan tersebut kita bisa mengetahui bagaimana efektivitas website sebagai media egovernment, mulai dari peran pemerintah, peran website, tujuan, jangkauan, content, interaksi, hingga faktor penghambat dan faktor pendukung yang menentukan efektivitas website sebagai media egovernment.

Informan yang berasal dari Pemda Jombang ada dua orang yaitu Agus Handoko ST yang merupakan webmaster yang mengelola website Pemda Jombang, serta Imam Sudjianto yang merupakan kepala Kanor Arsip, Perpustakaan dan PDE yang merupakan pengatur dan pengawas website Pemda Jombang. Dari kedua informan tersebut kita dapat mengetahui bagaimana efektivitas website Pemerintah Daerah Kabupaten Jombang menurut pemerintah.

Agus Handoko ST adalah webmaster yang merupakan orang yang bertanggung jawab untuk memelihara website, termasuk memastikan server web, perangkat keras dan perangkat lunak agar beroperasi secara akurat, merancang website, menghasilkan dan merevisi halaman web, membalas komentar pengguna, dan memeriksa lalu lintas melalui situs.

Imam Sudjianto adalah Kepala Kantor Arsip, Perpustakaan Dan PDE (Pengelolaan Data Elektronik) Pemerintah Kabupaten Jombang yang mempunyai tugas melaksanakan penyusunan, dan pelaksanaan kebijakan daerah yang bersifat spesifik di bidang kearsipan, perpustakaan dan PDE dan ketatausahaan, serta bertindak sebagai pengatur dan pengawas website Pemda Jombang.

Sedangkan untuk informan pembanding peneliti mewawancarai 3 informan dari warga masyarakat Kabupaten Jombang yang pernah dan aktif menyampaikan aspirasinya di website Pemda Jombang di link "buku tamu", yaitu Suparto, Widhie Paramudita, dan Setiadi. Dari ketiga informan tersebut kita dapat mengetahui bagaimana efektivitas website Pemerintah Daerah Kabupaten Jombang menurut masyarakat dan respons masarakat terhadap website Pemerintah /daerah Kabupaten Jombang

Suparno merupakan wiraswasta pemilik toko meubel yang lahir di Jombang, 12 Maret 1980. Beliau sering megakses website Pemda Jombang, selain itu beliau pernah menuliskan aspirasinya melalui link "buku tamu" pada website tersebut. Sehingga dari beliau dapat diketahi bagaimana efektifitas website Pemda Jombang menurut masyarakat dan respons masyarakat terhadap website Pemda Jombang. 
Widhie Pramudita merupakan mahasiswa semester akhir Universitas Darul Umum Jombang kelahiran Mojokerto 2 Januari 1991, yang sering megakses website Pemda Jombang. Sehingga dari dia dapat diketahi bagaimana efektifitas website Pemda Jombang menurut masyarakat dan respons masyarakat terhadap website Pemda Jombang.

Setiadi adalah wiraswasta yang mempunyai usaha dibidang seluler kelahiran Jombang 2 Agustus 1965 yang sering megakses website Pemda Jombang. Sehingga dari dia dapat diketahi bagaimana efektifitas website Pemda Jombang menurut masyarakat dan respons masyarakat terhadap website Pemda Jombang.

Metode Pengumpulan Data

Adapun metode dalam penelitian ini adalah:

1. Wawancara (Interview).

Wawancara merupakan teknik pengumpulan data dengan mengadakan tatap muka (Face to Face) secara langsung dengan cara berdialog dan tanya jawab, baik dengan informan maupun dengan pihak-pihak yang terkait lainnya. Guna memperoleh informasi atau data secara jelas dan mendasar, juga untuk menjalin hubungan dengan informan agar mempelancar dalam proses penelitian.

2. Observasi.

Observasi adalah metode yang digunakan untuk memperoleh gambaran secara langsung mengenai obyek penelitian, terutama yang berkaitan dengan implementasi perencanaan strategi pengembangan pariwisata.

3. Studi Literatur

Dalam studi literatur ini data diperoleh dari buku-buku literatur, jurnal-jurnal penelitian, makalah-makalah, majalah dan surat kabar referensi atau rujukan dari penelitian sebelumnya mengenai peristilahan, kerangka pemikiran dan teori yang ada serta relevan dengan pokok bahasan yang diteliti.

4. Dokumentasi

Merupakan teknik pengumpulan data dengan cara mencari, mencatat serta mempelajari data dari sejumlah arsip atau dokumen resmi yang ada di lokasi penelitian yang dianggap penting dan mempunyai relevansi dengan masalah yang diteliti.

\section{HASIL DAN PEMBAHASAN}

1. Efektivitas Website Sebagai Media E-Government

Website Pemerintah daerah Dapat dikatakan efektif apabila telah adanya interaksi yang bersifat pelayanan elektronik antara pemerintah dengan masyarakat.

Dalam literatur administrasi ataupun manajemen, kata efektivitas diartikan sebagai suatu keadaan yang mengandung pengertian mengenai terjadinya efek atau akibat yang dikehendaki [8]. Efektivitas ialah pengukuran dalam arti tercapainya sasaran yaitu tujuan yang telah ditentukan sebelumnya [9]. Jelaslah bila sasaran atau tujuan telah dicapai sesuai dengan direncanakan sebelumnya adalah efektif, sebaliknya bila tujuan atau sasaran tidak selesai sesuai waktu yang ditentukan, pekerjaan itu tidak efektif. Sasaran dan tujuan yang ingin disampaikan oleh pemerintah adalah isi informasi yang terdapat dalam website itu sendiri, sehingga dapat dijadikan patokan tolak ukur secara awam oleh masyarakat, jadi bisa dikatakan apabila website tersebut banyak yang mengakses dengan isi yang update [8], [9].

Selain itu Tolak ukur suatu website dapat dikatakan efektif atau tidak dipengaruhi oleh beberapa hal, antara lain peran website, peran pemerintah, tujuan, jangkauan akses, content, interaksi, faktor penghambat dan faktor pendukung. Apabila faktor-faktor tersebut dapat berjalan dengan baik, maka website dapat dikatakan efektif sebagai media e-government.

a. Peran website Pemerintah Daerah Kabupaten Jombang sebagai media e-government dalam meningkatkan pelayanan elektronik telah menjadi sebuah media untuk menyampaikan informasi

Berdasarkan United Nations E-government survey 2008, ada lima tahapan website sebagai media suatu negara yang bergerak naik menuju tahap pemerintahan yang yang lebih baik, dengan melalui berbagai tahap pembangunan infrastruktur, penyampaian konten, bisnis, manajemen data, keamanan dan manajemen pelanggan. Masing-masing website suatu negara menghadapi sejumlah tantangan serupa ketika bergerak ke atas piramida, dan isu bagaimana Amerika memenuhi tantangan akan menentukan kecepatan di mana mereka nergerak naik ke atas. 
Indeks pengukuran website memberika tahukan peringkat yang komparatif pada tiap negara mengenai kemampuan untuk memberikan layanan online kepada masyarakat.

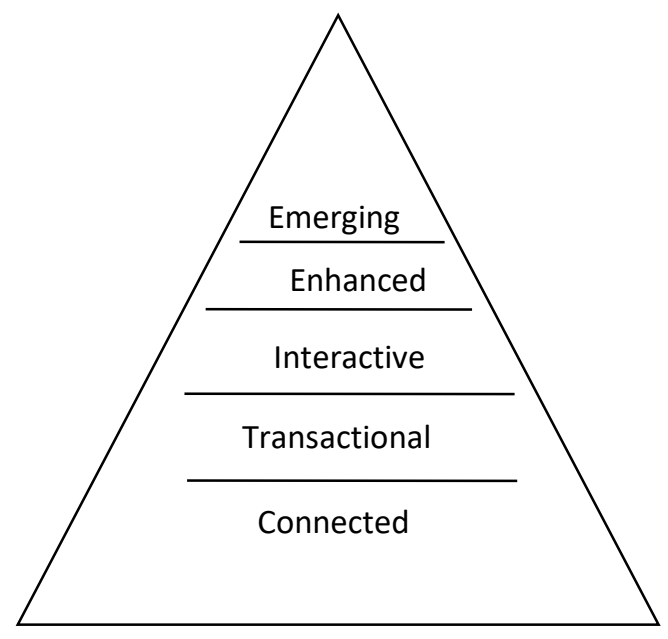

Gambar 5.1: Tahapan Perkembangan Website [10]

Tahapan Perkembangan E-Government, yaitu:

1. Tahap I-Emerging (kemunculan): Pada tahap ini website pemerintah Kabupaten jombang muncul dengan menyajikan berbagai informasi yang baik informasi mengenai pemerintah maupun informasi umum. Selain itu juga telah mulai ada interaksi, walaupun satu arah melalui link buku tamu.

2. Tahap II-Enhance (Peningkatan): Pada tahapan ini di dalam website pemerintah kabupaten Jombang belummemberikan informasi lebih jauh tentang kebijakan publik dan pemerintahan. Pemerintah Kabupaten Jombang belum memberikan link informasi yang mudah diakses oleh masyarakat, seperti misalnya, dokumen, formulir, laporan, hukum dan peraturan, dan newsletter.

3. Tahap III - Interactive (Interaktif):

Pada tahap ini Pemerintah Kabupaten jombang belum memberikan layanan online seperti bentuk download untuk pembayaran pajak dan aplikasi untuk perpanjangan lisensi. Selain itu, belum ada penawaran interaktif dari situs web dengan layanan untuk meningkatkan kenyamanan masyarakat.

4. Tahap IV - Transactional (Transaksi): Pada tahap ini dalam website Pemerintah Kabupaten Jombang belum ada interaksi dua arah antara 'warga negara dan pemerintah.

5. Tahap V-Connected (Koneksi): Pada tahap ini Website Pemerintah Kabupaten Jombang belum mengubah diri menjadi sebuah badan yang terhubung untuk menanggapi kebutuhan warganya dengan mengembangkan kantor infrastruktur terpadu.

Berdasarkan hal tersebut dapat diketahui bahwa website Kabupaten Jombang masih terbatas pada tingkatan awal, yaitu Tahap I yaitu Emerging (kemunculan) yang dimana masih tahap permulaan yang tentu saja masih perlu banyak pengembangan, sehingga dapat dikatakan website pemerintah belum bisa dikatakan efektif sebagai media e-government.

b. Pemerintah Kabupaten Jombang berperan besar dalam pengelolaan websitenya, mulai dari mengatur isi, tampilan, memberikan informasi dan berita.

Peran pemerintah dalam mengawasi perkembangan teknologi khususnya website juga diimplementasikan dengan cara mengelola, melakukan pengawasan, merevisi, serta memanfaatkan website itu sendiri untuk menyampaikan informasi-informasi yang patut diketahui masyarakat seperti informasi mengenai pembayaran pajak, rute transportasi, penyuluhan kesehatan, dan sebagainya. Masyarakat juga dapat menyampaikan aspirasinya kepada pemerintah mengenai kebijakan pemerintah yang kurang disetujui oleh masyarakat melalui link "buku tamu".

Website dapat dijadikan suatu media oleh pemerintah daerah dalam menjalankan tujuan e-government. E-government mengacu pada penggunaan teknologi informasi oleh pemerintahan, seperti menggunakan intranet dan internet, yang mempunyai kemampuan menghubungkan keperluan penduduk, bisnis, dan kegiatan lainnya. Bisa merupakan suatu proses transaksi bisnis antara publik dengan pemerintah melalui sistem otomasi dan 
jaringan internet, lebih umum lagi dikenal sebagai world wide web.

Sehingga dapat dipahami peran Pemerintah terhadap websitenya adalah sebagai pengelola, pengatur pengontrol dan pengawas yang dimana memberikan berita apa saja yang terbaru mengenai kabupaten jombang, baik itu informasi secara umum maupun informasi mengenai pemerintah Kabupaten Jombang, misalnya informasi adanya program-program maupun eventevent yang sedang akan dan sedang berlangsung, sehingga masyarakat Jombang bisa mendapatkan informasi dimanapun, kapanpun.

c. Tujuan peningkatan pelayanan publik Pemerintah Kabupaten Jombang melalui website adalah kemudahan dalam mengakses informasi kapan saja dimana saj, baik itu mengakses berita tentang pemerintah jombang maupun info umum seputar jombang, sehingga memudahkan masyarakat dalam mendapatan informasi-informasi yang tersedia di tiap "link", misalnya saja mau info umum tentang jadwal kereta api, harga sembako yang sesuai dengan aturan, atau info pengadaan barang dan jasa tinggal di klik saja linknya sudah bisa mendapatkan informasi yang aktual.

Sedangkan menurut masyarakat sendiri tujuan peningkatan pelayanan publik Pemerintah Kabupaten Jombang adalah agar masyarakat lebih mudah mendapatkan informasi. Misalkan adanya informasi pembuatan surat tertentu, atau pendaftaran CPNS sehingga masyarakat dapat langsung mengetahui berita yang paling akurat lewat website Pemda Jombang, karena jika berita tersebut dari pihak lain-lain selain dari Pemerintah langsung belum tentu kebenarannya, sehingga mempermudah masyarakat mendapat berita dimanapun kapanpun.

Sehingga dapat dipahami bahwa tujuan peningkatan pelayanan publik adalah kemudahan dalam mengakses informasi kapan saja dimana saja, baik itu mengakses berita tentang pemerintah jombang maupun info umum seputar jombang, sehingga mempermudah masyarakat mendapat berita secara actual dengan mudah dimana saja. Selain itu tujuan peningkatan pelayanan publik adalah agar meningkatkan keterbukaan dan kepercayaan terhadap pemerintah serta pemerintah lebih dapat mengetahi aspirasi masyarakat yang dapat bermanfaat untuk mencapai suatu tata kelola pemerintahan yang baik

Menurut Sinambela, secara teoritis tujuan pelayanan publik pada dasarnya adalah memuaskan masyarakat. Untuk mencapai kepuasan itu dituntut kualitas pelayanan prima yang tercermin dari: [11]

1. Transparan

Pelayanan yang bersifat terbuka melalui website Pemda Jombang mengenai pemerintah Pemda Jombang, juga mudah dan dapat diakses oleh semua pihak yang membutuhkan dan disediakan secara memadai serta mudah dimengerti

2. Akuntabilitas

Pelayanan yang dapat pertanggung jawabkan sesuai dengan ketentuan peraturan perundang-undangan.

3. Kondisional

Pelayanan yang sesuai dengan kondisi dan kemampuan pemberi dan penerima pelayanan dengan tetap berpegang pada prinsip efisiensi dan efektivitas.

4. Partisipatif

Pelayanan yang dapat mendorong peran serta masyarakat dalam penyelenggaraan pelayanan publik dengan memperhatikan aspirasi, kebutuhan dan harapan masyarakat, dalam hal ini dalam website Pemda Jombang melalui link "buku tamu"

5. Kesamaan Hak

Pelayanan yang tidak melakukan diskriminasi dilihat dari aspek apapun khususnya suku, ras, agama, golongan, status sosial dan lain-lain.

6. Keseimbangan Hak Dan Kewajiban Pelayananm yang mempertimbangkan aspek keadilan antara pemberi dan penerima pelayanan publik.

Website Pemerintah Kabupaten Jombang diharapkan akan mampu meningkatkan pelayanan karena lebih fokus terhadap masyarakat baik sebagai warga negara maupun pelaku bisnis yang menjadi inti dari agenda reformasi saat ini. Layanan yang berhasil apabila dibangun atas pemahaman kebutuhan masyarakat. Website Pemerintah Kabupaten Jombang dapat membantu mencapai tujuan Pemerintah Kabupaten Jombang sebagai organisasi terpadu yang 
memberikan layanan online. Masyarakat tidak perlu memahami struktur dan hubungan pemerintahan untuk berinteraksi dengan pemerintah sehingga layanan Website Pemerintah Kabupaten Jombang harus dikembangkan berdasarkan permintaan dan nilai-nilai masyarakat

Peningkatan pelayanan Website Pemerintah Kabupaten Jombang pada intinya akan bermuara untuk membantu meningkatkan keterbukaan dan kepercayaan terhadap pemerintah, serta berkontribusi terhadap tujuan kebijakan. Fokus pengembangan Website Pemerintah Kabupaten Jombang seharusnya dapat bermanfaat untuk mencapai suatu tata kelola pemerintahan yang baik dan bersih.

d. Jangkauan akses e-government mulai diperluas oleh pemerintah Jombang, seiring dengan semakin adanya area free wifi di tempat-tempat umum, dan semakin berkembangnya ilmu pengetahuan dan teknologi.

jangkauan aksesnya e-government pemerintah Kabupaten Jombang jika dibandingkan dengan kota-kota besar lain, seperti Malang, Surabaya masih kurang, namun sekarang jangkauan aksesnya mulai berkembang dengan baik, semakin luas, semakin banyak masyarakat yang sudah mengaksesnya. Hal ini bisa dilihat dengan adanya spot-spot dimana masyarakat bisa mengakses wifi secara gratis, contohnya saja alun-alun, selain itu perkembangan alat komunikasi saat ini semakin canggih jadi website Pemda Jombang juga bisa diakses lewat HP, atau ipad

Menurut www. kompas.com, jangkauan akses e-government pada umumnya dapat bervariasi karena dipengaruhi oleh berbagai faktor, meliputi: [12]

1. Jumlah perangkat (seperti komputer, laptop, telepon seluler, atau tablet yang digunakan untuk mengakses internet) per orang.

Belum semua masyarakat Jombang yang memiliki perangkat secara pribadi, hal ini dipengaruhi oleh status ekonomi dan pekerjaan.

2.Jumlah pengunjung pada lokasi yang dipilih.

Selain dilihat dari jumlah pengunjung yang dapat dilihat di website, jumlah pengunjung yang semakin lama semakin banyak juga dapat dilihat dari makin banyaknya masyarakat yang menyampaikan aspirasi, kritik dan saran melalui "buku tamu"

3. Durasi waktu yang dihabiskan setiap orang di situs web.

Rata-rata masyarakat menghabiskan waktu 20-60 menit dalam mengakses website Pemda Jombang.

4. Kunjungan ke Mitra Pencarian atau Jaringan Display Google ke alamat website "www.jombangkab.go.id"

Sudah banyak yang search "www.jombangkab.go.id" melalui google

5. Adanya spot-spot yang dapat mengakses wireless (wireless area)

6. Pemerintah telah memperluas spot-spot yang dapat mengakses wifi secara gratis contohnya alun-alun dan area perkantoran pemerintah.

Sehingga dapat dipahami jangkauan akses e-government sendiri khususnya di Kabupaten Jombang memang sangat bervariasi, dan tidak dapt dipungkiri bahwa faktor internal dari masing-masing masyarakat seperti education, ekonomi juga mempengaruhi masyarakat dalam jangkauan akses e-government. Selain memperbanyak wireless area, diharapkan pihak pemerintah juga mengadakan sosialisasi mengenai website Pemerintah Kabupaten Jombang.

e. Content e-government sudah baik, namun perlu diperbaiki dan ditambah dari managemen isi, misalnya saja adanya link-link yang memudahkan komunikasi dua arah.

Content e-government yang terdapat dalam sebuah website menggambarkan image dari suatu instansi yang ditampilkan, mempunyai desain yang menarik tidaklah cukup agar suatu website yang dibangun dapat menjadi website yang besar dan dikunjungi banyak pengunjung. perlu didukung dengan konten yang jelas, akurat, orisinil, dan sesuai target pengunjung. Beberapa konten yang wajib tersebut: adalah Home Page, Service/Product Page, Contact Page, About Page, Testimonials Page. Selain itu isi dari content tersebut harus diberbarui secara berkala agar tetap up-date dan aktual isi pemberitaannya.

f. Interaksi e-government dalam website Pemda Jombang sudah terjalin dalam link "buku 
tamu", namun interaksi yang terjadi masih berupa komunikasi satu arah saja.

Menurut Indrajit terdapat 4 (empat) macam interaksi antar pelaku dalam e-government, yaitu: [13]

i. G to C: yaitu Government to citizen, dimana interaksi antara pemerintah dengan masyarakat

ii. G to B: yaitu Government to Business, dimana interaksi antara pemerintah dengan lingkungan bisnis (swasta)

iii. G to G: yaitu interaksi Government to Governments, dimana interaksi antara pemerintah yang satu dengan yang lainnya

iv. $G$ to E: Government to Employes, yaitu interaksi antara pemerintah dengan karyawan

Sehingga dapat dipahami bahwa interaksi e-government dalam Website Pemerintah Kabupaten Jombang sudah terjalin dalam link "buku tamu", namun interaksi yang terjadi masih berupa komunikasi satu arah saja, jadi pemerintah yang memberikan informasi saja, atau masyarakat yang menyampaikan saran dan kritik saja. Untuk kedepannya baik oleh pemerintah maupun masyarakat, interaksi komunikasi dapat terjalalin "two way communication" dimana dalam website Pemerintah Kabupaten Jombang nantinya terdapat "link" yang dapat memfasilitasi interaksi dua arah langsung antara pemerintah dengan masyarakat, misalnya dalam bentuk fasilitas "chat". Sehingga fungsi website diharapkan tidak hanya berfungsi sebagai sumber informasi yang bersifat pasif, namun diharapkan bisa bersifat dinamis, sehingga fungsi dan peran website menjadi dua arah dan timbul efek timbal balik

2. Faktor Pendukung Website Sebagai Media E-government

Faktor pendukung Website Pemerintah Kabupaten Jombang sebagai media E-Government dalam memberikan Pelayanan Elektronik yaitu makin berkembangnya eknologi informasi sehingga semakin mudah internet diakses, makin banyak masyarakat yang aktif dengan tingkat pendidikan yan lebih baik, dan adanya evaluasi yang dilakukan oleh pemerintah kabupaten jombang mengenai informasi maupun tampilan sehingga adanya perubahan dan perbaikan penampilan website secara berkala.
3. Faktor Penghambat Website Sebagai Media E-government

Faktor pertama adalah dari masyarakat itu sendiri, dimana masyarakat yang sudah berumur dengan latar belakang pendidikan rendah belum bisa menggunakan peranti elektronik, sehingga belum bisa mengakses website, yang kedua belum adanya pengelola dari pihak pemerintah yang bisa secara langsung memberikan tanggapan atau interaksi dua arah antara pemerintah dengan masyarakat, yang ketiga belum adanya koordinasi dengan dinas lain yang memungkinkan adanya e-service, sehingga dapat mendownload dokumen melalui website, dan ketiga kurangnya sosialisasi kepada masyarakat mengenai penggunakan media website sebagai media e-government.

Adapun terdapat beberapa persamaan dan perbedaan penelitian ini dengan penelitian sebelumnya, persamaannya antara lain: website Pemerintah Kabupaten Jombang berfungsi sebagai sarana pemerintah untuk building image kepada masyarakat dan perlahan mulai terlaksana secara efektif. Selain itu melalui website Pemda Jombang, masyarakat bisa menyalurkan aspirasi melalui link "buku tamu" dan makin banyak masyarakat yang aktif dalam menyalurkan aspirasinya.

Sementara itu perbedaannya antara lain: Pada situs Pemda Jombang mulai berfungsi sebagai alat komunikasi oleh masyarakat walaupun masih bersifat satu arah, dan Sudah banyak masyarakat yang mengakses. Berbeda dengan penelitian sebelumnya Pada website Pemda Jombang sendiri sudah bukan tahap web presence lagi, namun sudah tahap fase interaksi dimana masyarakat sudah bisa berkomunikasi melalui link "buku tamu".

\section{KESIMPULAN DAN SARAN \\ Kesimpulan}

Website Pemerintah Kabupaten Jombang telah efektif sebagai media penyampaian informasi, namun sebagai media layanan elektronik (e-service) belum efektif, dengan faktor pendukung: makin berkem- bangnya teknologi informasi sehingga semakin mudah internet diakses, makin banyak masyarakat yang aktif dengan tingkat pendidikan yang lebih baik, sedangkan faktor penghambatnya: masyarakat yang sudah berumur dengan pendidikan rendah belum bisa menggunakan peranti elektronik, belum ada interaksi dua arah antara pemerintah dengan masyarakat, dan belum digunakannya 
website Pemerintah Kabupaten Jombang sebagai e-service

\section{Saran}

Adapun rekomendasi untuk penelitian selanjutnya:

a. Bagi Pemerintah Daerah Kabupaten Jombang

i. Pemerintah Kabupaten Jombang agar lebih optimal dalam memberikan pelayanan yang berbentuk elektronik melalui websitenya, agar lebih memudahkan masyarakat dalam mendapatkan pelayanan

ii. Adanya sosialisasi masyarakat oleh pemerintah Kabupaten Jombang mengenai penggunaan website, agar masyarakat makin mengenal dan dapat mempergunakan website semaksimal mungkin.

iii. Diadakanya fasilitas interaksi komunikasi yang dapat terciptanya "two way communication" dimana dalam website Pemerintah Kabupaten Jombang nantinya terdapat "link" yang dapat memfasilitasi interaksi dua arah langsung antara pemerintah dengan masyarakat, misalnya dalam bentuk fasilitas "chat"

iv. Pemerintah agar melakukan koordinasi dengan dinas lain dalam lingkup pemerintahan Jombang yang memungkinkan adanya e-service, sehingga dapat mendownload dokumen melalui website

v. Pemerintah agar melakukan koordinasi dengan dinas lain dalam lingkup pemerintahan Jombang yang memungkinkan adanya e-service, sehingga dapat mendownload dokumen melalui website.

b. Bagi Peneliti Selanjutnya

Diharapkan penelitian berikutnya dapat meneliti serta memperluas fokus penelitian, yang tidak hanya terbatas pada website sebagai media e-government namun media yang lain

\section{UCAPAN TERIMA KASIH}

Dengan mengucapkan Alhamdulillah puji syukur kehadirat Allah SWT atas kelimpahan rahmat dan hidayah-Nya, penulis dapat menyelesaikan jurnal tesis ini. Penulis mengucapkan terima kasih kepada:
1. Prof. Bambang Supriyono, MS selaku Dekan Fakultas Ilmu Administrasi Universitas Brawijaya

2. Drs. Andy Fevta Wijaya, MDA, Phd. Selaku Ketua Program studi Magister Administrasi Publik Universitas Brawijaya dan sekaligus ketua Komisi Pembimbing

3. Dr. Suryadi, MS selaku anggota komisi pembimbing

4. Kepala Humas Sekretaris Daerah Pemerintah Kabupaten Jombang

5. Kapala Kantor Arsip, Perpustakaan dan PDE Pemerintah Kabupaten Jombang

\section{DAFTAR PUSTAKA}

[1]. Nurudin. 2008. Hubungan Media: Konsep dan Aplikasi. Raja Grafindo Persada, Jakarta.

[2]. Thoha, Miftah. 2000. Peranan IImu Administrasi Publik dalam Mewujudkan Tata Kepemerintahan yang baik. PPs UGM, Yogyakarta

[3]. http://bapersip.jatimprof.go.id/bapersip/ka ntor perpus 38 kab kota detail.jsp?id=668), diakses 15 Agustus 2014

[4]. Moleong, Lexy. 2005. Metodologi Penelitian Kualitatif. PT Remaja Rosdakarya, Bandung

[5]. Moleong Lexy. 2005. Metodologi Penelitian Kualitatif. PT Remaja Rosdakarya, Bandung

[6]. Moleong, Lexy. 2000. Metodologi Penelitian Kualitatif. PT Remaja Rosdakarya, Bandung

[7]. Miles, Matthew dan Huberman, A. Michael. 1992. Analisis Data Kualitatif: Buku Sumber Tantang Metode-Metode Baru. UI Press, Jakarta.

[8]. Gie, The Liang. 2002. Analisis Administrasi Dan Manajemen. Gramedia, Jakarta

[9]. Handayaningrat, Soewarno. 2002. Pengantar Suatu Studi IImu Administrasi dan Manajemen. Gunung Agung, Jakarta.

[10]. http://unpan1.un.org/, diakses pada tanggal 2 Februari 2014

[11]. Sinambela, Lijan Poltak. 2006. Reformasi Pelayanan Publik (Teori Kebijakan, dan Implementasi). Bumi Aksara, Jakarta.

[12]. http://forum.kompas.com/internet/299665 -12-keunggulan-menggunakan-googleadwords-untuk-beriklan-di-internet.html, diakses pada tanggal 24 November 2013

[13]. Indrajit, Richardus Eko. 2004. E-Government Strategi Pembangunan dan Pengembangan Sistem Pelayanan Publik Berbasis Teknologi Digital. Andi Offset. Yogyakarta. 